\title{
Un Earthing the Reasons Behind the Human Behaviour in Society: A Re- appraisal of the Theories in Sociological Behaviourism
}

\section{Tesky Timothy Agoben*}

Department of Sociology, Faculty of Social Sciences, University of Lagos, Ndufu-Alike, Ikwo, Nigeria

${ }^{*}$ Corresponding author: Tesky Timothy Agoben, Department of Sociology, Faculty of Social Sciences, University of Lagos, Ndufu-Alike, Ikwo, Nigeria, Tel: +234-1-7339832; E-mail: agobenteskygmail.com

Received date: Mar 27, 2018; Accepted date: June 13, 2018; Published date: June 20, 2018

Copyright: () 2018 Agoben TT. This is an open-access article distributed under the terms of the Creative Commons Attribution License, which permits unrestricted use, distribution, and reproduction in any medium, provided the original author and source are credited.

\begin{abstract}
Human behavior in any society is influenced by a host of factors, and understanding or unearthing the reasons behind such behavior is usually not an easy task. It was because of these difficulties and quest to unravel the motives behind human Behaviors, that 'Theoretical Behaviorism' arose as a movement. To understand how and why humans behave in certain ways, when they respond to various stimuli, situations or beliefs in the human environment; some 'Sociological Behavioral Theories' have been put forward and analysed; to explain human actions. In a bid to understand human actions better, these Sociological Behavioral theories were re-appraised. Among the theories selected and reappraised to explain human Behavior better are: 'The Functionalist view, the Conflict theory view of the Feminist and Marxian scholars, Positivist school, Symbolic interactionist school, Max Weber Social Action and the Social Exchange Theory'. This theoretical reappraisal also differentiated 'Behaviorism' from 'Behaviorism'; and suggested the 'Ethnographic' approach which requires participant observation, as an alternative model for understanding human Behavior in case the Sociological Behavioral theories becomes inadequate. Finally, this theoretical reappraisal predicted possible future actions in Nigeria using the sociological theories of Behaviorism.
\end{abstract}

Keywords: Human behavior; Behaviorism; Sociological behavioral theories

\section{Introduction}

\section{Origin and meaning of behaviorism}

The main theme of Behaviorism focuses on observing, understanding, predicting and controlling human behavior within a social setting. Behaviorism as a theoretical movement is concern with the systematic approach to the understanding of human behavior. It asserts that, human behavior involves reflexes and calculated actions, produced by a response to certain stimuli, situations, beliefs or ideas; in the human environment and this usually manifest as a form of response to punishment or motivation resulting from Behavior.

Though there are different versions as to how Behaviorism emerged, excerpts from the 'Approach to Psychology' states that, the earliest traces and derivatives of Behaviorism, dates back to the late 1800s when Ivan Pavlov, a Russian Physiologist, published the result of his experiment on conditioning, after studying the salivation of dogs before they are fed and their digestion after being fed. This was followed by Edward Thorndike who pioneered the law of effect (a process that involved strengthening behavior through the use of reinforcement) and it combines the elements of philosophy, methodology and psychological theory. After Pavlov and Edward; J. B. Watson in his Ph.D. thesis 'Psychology as the Behaviorist Views it', launches the Behavioral school of psychology and through this, psychology was as that time, viewed as purely objective experimental branch of the natural science. The work of J. B. Watson was followed by that of B. F. Skinner who worked on the behavior of organisms, and through this work, he introduced the concepts of 'Operant
Conditioning and Shaping in Psychology'. After B.F. Skinner's work, other scholars such as Albert Bandura, with his social learning theory and personality development; coupled with Clark Hull's principles of behavior, threw more light on behaviorism before other modern scholars came into the field [1]. Hence, we can say that Behaviorism was a concept that emanates from the physiological to the psychological realm; before it was adopted by sociological scholars such as Max Weber, George H. Mead, Charles H. Cooley, Erving Goffman and a host of others in explaining and understanding human Behavior.

\section{Note: Please note that 'Behaviorism is different from Behaviorism'.}

Behavioralism: This is a concept developed by a political scientist named J. B. Watson in the 1930s in the United States and its main focus is on examining the Behavior, actions and acts of individuals as it relates to the political system rather than examining the characteristics of the legislatures, judiciary, executive or groups in social setting.

\section{Major types of behaviorism}

- Methodological Behaviorism

- Radical Behaviorism

- Psychological Behaviorism

Methodological behaviorism: This was proposed and developed by J. B. Watson and it asserts that only public events of individuals can be objectively observed and therefore private events should be ignored. This is the area of Behaviorism most sociological theorist focused on in their analysis or quest for understanding the key elements behind human Behaviors.

Radical behaviorism: This focuses on using laboratory experimental analyses that are used in the natural sciences to understand human 
behavior. Its focus was on using experimental analytical method such as the operant conditioning and then observe how animals reacts to stimulus in a laboratory setting before applying their findings to understanding human behavior in society [2-4]. The Positivist largely subscribes to this kind of approach.

Psychological behaviorism: It focuses on the practical control of Behavior through the use of token reinforcement and punishment to improve or discontinue a certain Behavior.

\section{Early variations of behaviorism in sociology key ideas}

The early varieties or variations of Behaviorism in sociology focus on the explanation of human behavior in the society through any or a combination of the following:

- By directly observing human Behavior as they respond to stimuli or external societal and environmental factors like the Positivist opined.

- By the ways structures of society determine how humans should behave, due to the presence of norms and values, which guides their Behavior like the functionalist perspective claimed.

- By watching as humans direct their Behavior to events that economically favours them; like the Marxist emphasized.

- By understanding human Behavior as they interact or engage in various social activities with other humans in the social process like the symbolic interactionist believed.

These early forms of Behaviorism highlighted above and others such as Weber's social action, Sociobiology of Behavior, the Feminist perspective, Dramaturgy and the Social Exchange theory will be evaluated in the course of this review. Let's embark on a step-by-step analysis of some of these aforementioned variations and how they explain the reasons behind human behavior in society.

\section{The Functionalist view of the reasons behind human behavior}

For the functionalist, their observation about human Behavior begin by emphasizing that, human Behavior or action is a function of the social structure, and human Behavior is largely determined by values, norms or rules that are guiding such a society. This means that, human interactions, Behavior or action in a society or individual Behavior towards other members in the society, are organized or determine by the type of laws, rules, values or norms that stipulate how people should behave in such a society. For instance, the way a woman who is from Saudi Arabia, Egypt or Pakistan will dress with hijab ontop her sport wears; while participating at the Olympics is entirely different from the way an American, French, Burkinababe, Nigerian or a Mostwana woman will dress at the Olympics or any other sport events. This is because, their society (i.e. Egypt, Pakistani, Saudi Arabia) which are predominantly Muslim, frown at women that open their body (without hijab) in the public. This assertion could also be used to explain why lesbians and gays do not and cannot publicly display their affections to each other in Nigeria. This is because, the social structures of the Nigerian society; such as the constitution, values of Christendom churches or the family institution, frowns at such a Behavior and sees it as a taboo.

According to the functionalist, values provide the general guideline for Behavior in a society and this is because, they provide overall belief of what is bad and good. Societal rules and norms specify the type of Behavior that is expected of individuals occupying certain roles They don't just behave or act the way they like; they must follow what their society requires $[5,6]$. For instance, in the western world, a Doctor is expected by societal values or structure to be someone who is intelligent and should work in hospitals saving lives. Thus, if a Doctor refuses to treat a dying patient because he has closed from his official duty, and he is late for a party or church service, his behavior is seen as abnormal, mal-value and will be frown at. But if a secretary in the same clime refuses to type a letter or attend to a visitor because she has closed from official duty, or have become late for a family re-union party, her behavior will not be seen as abnormal; this is because the structure of her society do not attach much importance to her job. Also, while it is permissible for a Nigerian Teacher to administer a reasonable level of physical discipline (such as flogging, clearing grasses or kneeling down) on his or her students if they misbehave or forget to do their homework, it is totally wrong and against the social norm in western countries like Germany, United Kingdom, Spain etc. to apply such disciplinary measures $[7,8]$. While the Nigerian social structure allows individuals to give birth to as many children as they want, it is constitutionally wrong in China to give birth to as many children as you want. While a young female adult can become pregnant and abort her pregnancy at will in countries that legalize abortion, it is constitutionally or morally wrong to attempt such act or make such behavior public in countries like Nigeria. Thus, a society with an organized social structure generally has a large number of her citizens with organize Behavior; though there might be few cases of deviance and rebellion. Hence, we can say countries like Nigeria or Sudan with dis-organize social structure and political system; will have a large number of their citizens with disorganize Behavior. That is why it is permissible in Nigeria to embezzle public funds, unlawfully arrest citizens, eat food, drink sachet or bottle water and throw the refuse carelessly without being questioned. Meanwhile, the same Behavior is wrong in organized climes like Germany or England, United States of America that have organized socio-political structure and value system. Social structure according to the functionalist, explains why political and convicted criminals like James Ibori and Bode George were celebrated in Nigeria churches but Sigmundur Davio Gunnlaugsson who was the prime minister of Iceland resigned because of being criminally indicted in the Panama papers. This different events and actions highlighted above shows that, the structure of a society determines the way people react to issues and are being treated.

\section{Limitations and Criticism}

The functionalist perspective has been criticized for a number of reasons.

First, the social structure or value systems are usually the views, values or structure imposed and dictated by the ruling class upon the larger population in that society. Thus, the behavior promoted or directed by the social structure is the view held by the ruling class and not necessary the social institutions.

Second, they fail to recognize that the conflict of humans arising from unacceptable Behaviors of others will affect the society and social structure. Hence, the behavior of humans is seen as affecting and dictating the nature and pattern of the social structure a society will have.

Finally, the functionalists forget the role of individual or group values arising from group solidarity. Such that, people prefer to be loyal to their group values even if they are in conflict with societal wild held norms and values. For the example, the Bokoharamists, ISIS or Shites 


\section{The Marxian Conflict Perspective of Human Behavior}

According to the Marxian theory, human Behavior in any society is determined by economic activities as it relates to the means of production and the gains that individual derives from it. The Marxian perspective emphasized that, whatever form of Behavior humans exhibit in society; is aimed or geared towards gaining and having access to the economic means of production. He opined that, human actions do not just happen for any reason, there must be something they want to gain economically. All human actions or Behavior according to them, is controlled or determined by something that has economic benefit to the individual or group of individuals. That is to say, no human ever takes an action because of pious motive, it must have economic reason. This assertion is sufficient to explain why student come to class or do their assignments. It is not primarily because they want to know, but because they want to get the mark or scores in a course that will enable them graduate and have access to economic means of life through employment. Also, it explains why women agree to marry a particular man and reject marrying others. The Marxian view is saying that, a woman will agree to marry or date a man because of the economic benefits that will accrue from such relationships. People do not just become nice, there is something they want to achieve. People don't just go into robbery, there are economic benefits. A young man doesn't just dress well, he wants to impress a woman or other girls with his wealth that he has arrived and should be taken important too. University of Lagos don't just give scholarships or academic awards to students, they want to be able to amass external funding, endowments or other forms of donations from the public. Professor Nduka Nwabueze who is a lecturer, is not just coming to class to teach or increasing and intensifying his research work; because he loves publishing books, articles and journals, but because he wants to become a Distinguished Professor and improve his earning capability and become more economically established among his peers and contemporaries. The Behaviors that can be predicted using the Marxian perspective goes on and on.

\section{Limitations and criticism}

The Marxian perspective has been criticized for a number of reasons. First, they fail to acknowledge the role religion plays in determining human behavior and this should prove to them that not all behaviors are directed to achieve economic means. The Marxist cannot explain the behavior of terrorist and extremist such as Bokoharam, ISIS or Ashbab, which many times embark on revengeful attack to pay back previous offenders or to make their voice heard in the international community.

Second, the social structure and societal norms also have a way in determining how we behave even if the behavior is supposed to be directed towards achieving economic means. For instance, there are rules or social structure such as the welfare system which latently deters people from working because of collecting a maintenance wage even when they don't work.

Third, the Marxists fail to explain the role socialization and group values play in shaping humans to behave in certain ways.

Finally, they fail to explain the reason why people engage in pleasure seeking activities like tourism, sky diving, swimming, playing football or basketball without having an economic motive in mind.

\section{Feminist Conflict Perspective and Human Behavior}

Oakley outlined how socialization in modern societies shapes the behavior of girls and boys from an early age. The main theme of the feminist perspective stressed that, humans are socialized to behave in a certain way as a result of their sexes. They emphasized that, boys or girls behave in a certain way because they have been instructed, socialize or socially shaped to behave and act in a certain way. The selfconcept is affected through manipulation like dressing girls in feminine clothes. Differences in boys and girls are achieved through canalization by directing girls and boys towards different objects. E.g Boys usually play football, guitars or use guns as toys while girls have doll baby's as toys to rehearse their expected role as mothers. Boys have always seen themselves as the head of the family because they have been socialized to see themselves and behave as such. Also, the use of verbal applications such as: boys don't cry, girls don't fight or girls should be gentle and good looking are used to alter behavior of children while they are growing up. The women care for the homes, take care of children because they have been socialized to behave in such a way.

According to the feminist, society frowns at a woman when she exhibits a particular behavior because she has not been socialized to behave in such a way. That is why it is generally wrong in most (if not all) African cultures, for a woman to marry more than 1 or 3 men at the same time, because society generally frowns at a such an action, but the same culture allows a man to marry more than 3 women at the same time. Also, the feminists assert that, the behavior of any woman is largely due to socialization or due to the societal limitations placed on her. That is why within the Africa clime, it is socially wrong for a woman to express her romantic interest first; for a man she loves since she will be seen as cheap woman. The feminist view can be used to explain why girls don't give birth to a child and hand it over to the man to carry since they have been socialized to do such. It is also used to explain why men generally feel they are superior and stronger than women. Thus, if a woman physically over powers a man, it is seen or view that the man has not measure up to his social expectation and if a woman is the primary bread winner of the family, it is viewed as a societal misnomer.

\section{Criticisms and limitations of the feminist perspective}

The feminist perspective was criticized for the narrow idea on the difference between male and female which they believed was not natural.

First, Nickie Charles noted that, Oakley's approach does not explain why in most societies men and not women are socialized into a dominant role.

Second, Bob Cornell criticizes the feminist for portraying socialization as a passive process in which children just absorb or accept what they learn from parents and other agents of socialization. This is because, the (i.e. feminist scholars) negates the area of resistance to socialization where some boys don't like football or male toys, and some female children who have passion for stereotyped male carriers.

Finally, the feminist scholars fail to understand that socialization based on gender specification alone does not determines an individual's total behavior. They forget the role that religion and group beliefs or individual goals have on the behavior of every human. 


\section{The Positivist View and their Understanding of the Reasons behind Human Behavior}

The positivists believed and assumed that, the Behavior of humans is like that of matter and can be objectively measured and interpreted through observation. They opined that, in order to measure or observe the reaction of a certain chemical to heat, it is necessary to provide the exact measurement, temperature and physical conditions that can make such chemical to react to heat, then observe its Behavior carefully and report its cause and effect relationship. Once it has been shown that the matter in question reacts the same way to the temperature and other physical properties under a fixed condition, then a theory can be devised to explain the Behavior of matter in a natural setting and apply the same method and theory to explain and observe human Behavior [2]. They argued that, factors such as feelings, meaning that cannot be directly observed are misleading, and should not be used to study human Behavior.

The emphasis of the positivist is on observable facts and humans react to stimuli in their environment, hence their Behavior can be explained by observing the way they react to stimuli or social issues. The positivist views can be used to explain most social unrest in western societies and a few of African cities. For instance, when individuals or members of a society are threatened with stimuli such as marginalization, oppression, denial or any other form of social inequality, they respond by fighting back in the form of protest, social movements, strike, revolution or through flight by running away from the situation to save themselves. From the positivist view, a student will protest if he's unjustly expelled from school, a lecturer or lecturers will embark on strike if they are stimulated with salary denial for a long time, workers will protest if their entitlements, salary or working conditions are denied. The positivist view can also explain why citizens react to news or events of war by running away to other safe environment or countries. The case of the Syrian citizens who reacted to the stimuli of war by running to a safe country like Germany can also be explained with this Behavioral theory. They also assert that, people go into marriage because society stimulate them to, and when the pressure or stimuli from other members of the society is too intense, people react to the stimulated pressure by getting married so as to give birth to children.

\section{Limitations and criticism}

The Positivists have been criticized for adopting the scientific analyses of studying the behavior or reaction of matter to the understanding of human behavior.

First, the positivists were attacked for not being able to explain why different societies respond to the same or a particular stimulus in different ways whereas all matters will respond to a particular stimulus the same way. For instance, gas and a spark of light will produce fire every time, water and sugar when put together will always dissolve into a water solution. But people will respond to death in different ways in various societies. Some mourn while others celebrate the departed, some bury their dead and some burn their loved ones who have died.

Second, the positivists also forget to explain that not all human society respond to changing physical circumstances. For example, Nigeria and most African countries have endured and adapted to bad or some of the world worst governments without the outbreak of revolutions like what we had in France or Great Britain, rather what you see in these countries is support from a few benefiting quarters for the government in power.
Third, they forget the role rationalization of action plays in human behavior and that even if there are certain stimulus; they can decide to respond in a certain way. For instance, exposure to fire burn is supposed to make humans flee to safety but there had been incidents of people who self-immolate (i.e. put fire on themselves). Also, the desire to acquire wealth or material wealth is supposed to be interesting to humans but there are those who choose to be poor because they have a religious faith that the poor will inherit the kingdom, hence they believe their reward is in heaven and wealth on earth is fruitless.

\section{Social Action and Max Weber Contribution to Understanding Human Behavior}

Max Weber contributed to the understanding of human Behavior (i.e. Behaviorism) through his work on Social Action. Social action or Behavior according to Weber, is social, it is (i.e. Behavior) social because, of the subjective meaning that actors attached to their action and because action does not take place in isolation but in connection with other members of society.

This is because, it takes into account the Behavior of other actors and this will make the person (i.e. actor) to model its Behavior to suit the expectation of onlookers.

To Weber, social action was an action or Behavior carried out by an individual and which other individuals attached meaning. According to Weber, "An action which takes account of the Behavior of others and is thereby oriented in its course; is a social action but if it does not take account of the Behavior of others, then it is not a social action". Also, an action (though may happen in public) which a person does not think of; is not qualified to be called a social action. For example, an accidental collision of cars, motorcycles or a plane crash is not qualified to be called a social action. It should be noted that, if an action or behavior does not take note of the existence or possible reaction of others, then it is not a social action or behavior. For example, a young girl praying in the closet, a teenager watching pornography in the room alone does not qualify as social actions or Behavior according to Weber. But if the same set of individuals, the young girl for instance starts praying in her church including other church members, there is a greater tendency she will mind the words coming from her mouth during her prayers and this is what Weber calls social action.

Weber does not subscribe to causal or observational understanding of human Behavior. To adequately understand human Behavior, Weber use the term 'Social Action and Verstehen' a German word which means 'Social Action and Understanding', with this, he explained that, for us to understand an action or Behavior, we have to divide understanding into two (2) types and these are:

\section{- Direct and Observational Understanding \\ - Explanatory Understanding}

In the first category, that is the Direct and Observational Understanding, we can easily understand that a person is happy or joyous by observing their facial expression; hence we can observe that he's happy. However, in the second category of understanding (i.e. explanatory understanding), it is difficult and very difficult for us to explain why he's happy. And even if we ask questions to get a better understanding of the reason for his Behavior, the subject under-study or being observe might not be truthful. To achieve the second type of understanding according to Weber, we need to put ourselves in the situation of the person who is exhibiting this behavior before we can 
explain it. Moreover, Weber stressed that, even the causal explanation of action or behavior is not sufficient enough to explain series of actions or events. With these identified limitations, he advocated a method closer to the positivist approach and he used this to discover connection between events, and established a causal relationship between these events.

One of Weber's explanations of causal relationships between events can be seen from his study of 'Religious and Bureaucratic Institutions'. Let's examine two of such causal relationships as they determine Behavior; by examining 'Religious Beliefs and Behavior and Institutional Goals and Behavior'.

\section{Religious Beliefs and Behavior - 'Themes from the Protestant Ethics and Spirit of Capitalism'}

After his study of countries with Protestant and Catholic Churches under the religious sphere, Weber tried to show that there was Ascetic Protestantism and the rise of capitalism. He (i.e. Weber) found out from his study that, Protestants have a belief that, they are predestined to go to heaven and for them to attain the predestination of going to heaven, they have an obligation they must fulfill. And that obligation is, seeing their work on the earth as that which was given by God and it is only profits or proceeds from their work, that can and will show (during inspection by God and his angels) that they qualify for the heavenly position. Thus, they have to save and increase their earnings and re-invest previous earnings to earn more. Therefore, the greater your works are, the greater your chances of attaining the heavenly predestination. With this widely held group beliefs of the Protestants, Weber came to believe that; 'beliefs held by a large group of people such as the protestants, can bring about large scale change of behavior and significant social change in a society'.

From the postulations above, a lot of religious group Behavior in our environment can be explain. For instance, it explains why Jehovah witnesses always carry bag to preach and do not accept blood transfusion even when under intense medical condition because of a bible belief and warning found in Genesis 9:4, Acts 15:29, that they hold on to. It also explains why Deeper Life female members don't put on make-ups, use weavongt to make their hair or work in a company like Nigerian breweries that produces alcohol or the Sabatharians who believed Saturday is the rightful day to worship God. These highlighted Behaviors by a group of worshipers are caused by religious beliefs held by a group within a society.

\section{Institutional Beliefs, Goals and Behavior - 'Themes from Weber's Study of Bureaucratic Organizations'}

For emphasis sake, I (Agoben, Timothy Tesky) will like to state that; the study of bureaucratic organizations by Weber explains how human Behavior is directed, control and organized by social bureaucratic institutions with the aim of attaining organizational goals, and this is achieved by adjusting employees' action or Behavior through set-out rules and principles; to fit in with the beliefs of the organization. In this review, he (i.e. Weber) explains how bureaucratic powers, set-down rules and regulation are used to control human Behavior by restricting their freedom and modeling or forcing them to behave in a certain way. Here, human Behavior or social action is geared or directed towards the attainment of organizational goals. Hence in this instance, the goals and objectives of bureaucratic organizations is what determines the Behavior of the individual. His or her freedoms are restricted to a certain level, the Behavior the individual exhibits must be in tandem with the organization bureaucratic goals. A good example of how human Behavior is directed by bureaucratic organizations can be seen from Military men, Police Officers, Immigration or Customs Officers wearing their professional uniform in the course of performing their duties, or of managers in the banking sector, cashiers, receptionist, air warden who must officially dress in organizational specified type of clothes even if they don't like wearing such clothes. It can also explain why University of Lagos students' or any other person coming into University of Lagos from Yaba or Bariga; must queue to enter the Danfo buses instead of rushing and scrambling for buses like other Lagos commuters usually do. Ordinarily every human like to be sociable by attending parties or relating with others, but institutional or bureaucratic goals restricts the Behavior of judges in this area by deterring them from attending social functions if it is not directly related to their immediate family members $[9,10]$. The reasons for the above highlighted organized group Behaviors is because of laid down rules directed to achieving organizational goals.

Weber further explained that, for an action or Behavior to be rational, the action must be meaningful and the meanings attached to such Behavior must be appreciated. He explains this further by identifying various types of action underlying human Behavior and these are:

- Affective: Actions or Behaviors emanating from our emotional state and example of this is fear, flight, fears, anger, tears amongst others.

- : These are Behaviors emanating from our customs or way of life. These are habits form from our birth place and example include the issue of not marrying an Osu (i.e. a slave) among the Igbo ethnic group in Nigeria or the forbidding of iguana and snail by some ethnic clans of Delta State of Nigeria.

- Rational action: These are Behaviors or actions we exhibit because of being aware of a certain goal we need to attain or achieve. They also consist of Behaviors or actions which are seen as right in our society. A good example is getting married, having children, earning a degree or serving a supreme being. These actions stem from Behavior generally approved in our society and seen as right by everybody.

The characteristics of Behavior (i.e. social action) according to Weber must entail the following:

- It must have relationship with the action of others, whether it is past, present or a future action.

- Behavior or social action is not isolated; because the Behavior exhibited is geared towards the Behavior or action of animate things.

- Weber emphasized that we cannot understand humans by mere looking at statistical figures.

- This is because; statistical figures might represent people's activities but the need to be interpreted so that people can understand these figures. Thus, the best interpreter of human Behavior is by someone who has been there and that person can understand the feelings and motivations of the people they are studying.

- Weber also stressed that, we should pay attention to subjective meanings, - that is - the way people interprets their own Behavior. The reason behind this is because, we as individuals cannot give an objective explanation of people's Behavior unless we look at how people view themselves and explain their Behavior. 


\section{Limitations and criticisms}

Weber has been criticized on his religious study for failing to explain Behavior stemming from people achieving goals or completing task for the pleasure of it. For instance, the endurance trek or man O'war activities by its members, football, basketball, rugby or other sport fans who support their teams for the pleasure of it. Secondly, rationalization of Behavior in society can be imposed on other members of society who will want to behave differently; the Nigeria's homosexuals for instance prefer to have sexual relations with their kind of gender, but they refrain from engaging in this Behavior because of the rationality imposed on them by the larger society.

To explain Behaviorism further, George Hebert Mead stressed that, humans show their Behavior through the use of symbols, to establish meanings and actions and this will take us to the Symbolic Interactionist School which will be our next focus.

\section{Symbolic Interactionism Views on Human Behavior}

Symbolic interactionism is a theoretical perspective which views or sees society as being composed of symbols that humans used to establish meanings, develop their views of the world and other humans within the society they found themselves; and act or behave in a certain way using these established meanings or symbols. In essence, symbolic interactionist analyzes the way we define ourselves and others form the basis and foundation of our Behavior. The originator of the symbolic interactionist school, a Scottish moral philosopher emphasized that, humans evaluate their own Behavior by comparing themselves with others. After him, scholars such as William James and John Dewey who were in the Psychology realm added to the analysis of the symbolic interactionist school. This theoretical perspective was brought into sociology by Sociologist Charles Horton Cooley, George Hebert Mead and Williams I. Thomas [3].

Symbolic interactionist tries to explain human Behavior and human society; by explaining and examining the ways in which people interpret their actions from intergroup relations or interactions with other members of society. They also (i.e. individuals) develop a selfconcept or self-image from these interactions and act in a certain way, in terms of the meanings develop from these interactions. They also believed that, the social structure is fluid and it is constantly changing as a result of human interaction. For the interactionist, symbol are very vital for social life and our ourselves. This is because we use symbols to perceive ourselves in a certain way; such as being beautiful, young, rich, handsome, intelligent, tall, short etc. and it is these symbols of self-perception that enables us to behave in a certain way in any social relationship or interaction we find ourselves. We also attach certain symbols to other people and these attached symbols enable us to behave in a certain way towards them.

In our social relations with others, we attach symbols such as 'Father, Mother, Uncle, Aunt, Brother, Lecturer, Doctor, Nurse, Barrister, Footballer, Musician, Soldier, Police' etc. and these attached symbols help us to coordinate and control our Behavior in our social relationship with these aforementioned groups of people. A very good example of how people behave to others based on interpreted symbols of interaction was a real-life experience with Doctor Michael Kunnuji by the first year of undergraduate programme of Sociology at the University of Lagos. As 100 level students, they were expecting a lecturer who will teach them Nigeria's Peoples and Culture, their expectation was of an elderly or mid-aged man with bears, large physiological features; since they have not met him before and that was the first time of meeting him, everybody was anticipating to see him. But few hours to the class, they saw a young man with a small physiological features, and a fairly cool voice, their reaction first through the class representative was: "Young man, what do you want, we are expecting to have a lecture here, where are you going to? Please you can't come inside now because we have a lecture here and the lecturer will soon be here". His reaction was: "What level is this? And the whole class replied 100 level, and he replied, my name is Doctor Michael Kunnuji and I can see you people are very rude, I am going to report you to your Course Adviser and tell him you prevented me from teaching your class". At that time, they realized he was the lecturer they were expecting.

The above highlighted experience took place, because of the kind of symbols the students attached to whom a university lecturer should be; since all the ones they have come in contact with within their few days in the university were mid-aged or a little bit elderly. Hence their symbols of a lecturer resulted in trying to chase Doctor Michael Kunnuji away, because we had a wrong symbol of him; as a fellow student who may be of a higher level or in a different department in the faculty. Thus, the Behavior we exhibit to others is as a result of the concept or interpretation we have of them and ourselves. These expectations corroborate with the postulations of Charles Horton Cooley in his work on the 'Looking Glass Self which will be our next area of discussion and analysis.

\section{Charles Horton Cooley and the Looking-Glass-Self}

In order to explain how humans' behave, he developed 'the looking glass self' concept which focuses on the way humans develop a selfconcept or a picture of themselves to determine the way they exhibit their Behavior. Actors tend to act in terms of their self-concept, and the way others interpret their reactions from the interaction process and this usually occurs through construction of meaning arising from the interaction processes. The self-according to him, is the interpretation of how others see us and our sense of self develops from interaction with others through these 3-elements of the looking glass self which are:

- Imagining how we look to others,

- How we interpret the Behavior (i.e. action) and reaction of others and

- How we develop ideas, feelings, picture of ourselves (self-concept) through the reaction and Behavior of others towards us.

For instance, the way 'Nigerian Politicians' carry themselves while on official assignments within the country is different from the way they behave when they travel overseas. When they are in Nigeria, they refused to take public transport or go to public hospitals for medical treatment; but travel with a long line of convoy with all manners of siren, security personnel and personnel assistants to announce their presence. However, these same politicians will travel to the United States or other European countries and behave like ordinary humans, contrary to their Behavior as demi-gods while in Nigeria. The reason for this, is as a result of the symbols they attached to themselves as being rich, important or first class citizens in Nigeria and this is partly because, of the symbols we the citizens attached to them as important personality.

All these highlighted elements were all brought to limelight by Cooley. It should be noted that, the development of the Self-concept does not depend on accurate evaluations. This is because, even if we 
misjudge how others think about us, those mis-judgements form part of the way we see ourselves. There are instances of individuals who interpret every evaluation of others as negative and they are called 'paranoids' while those who interpret every evaluation or even criticisms to be positive are called 'pronoid' [1].

\section{Erving Goffman Dramaturgy on the Analyis of Human Behavior}

Sociologist Erving Goffman added a new twist to symbolic interactionism when he developed 'Dramaturgy' (or dramaturgical analysis). By this term, he meant that, interaction in social life is like drama on stage; where people are merely performers or actors managing their behavior.

- Everyday life according to Goffman involves playing our assigned roles in the stage of life like actors do. And the same setting can serve as both front and backstage. For example, being in our room alone can serve as back stage and being in the same room with other people is likened to front stage.

- Everyday life provides us with many roles and in each role, we are expected to act or behave in a certain way.

- In performing roles, there are roles conflicts and these roles conflicts arise when what is expected of us in one role is incompatible with what is expected in another role and this makes us uncomfortable.

Also, there are role strains; this arises when there are inherent conflicts when performing the same role. At the centre of our performances in everyday life is the concept of -SELF- and how we want others to think of us. We use our roles to communicate with others the type of ideas we want them to form about us, and this was called by Ervin Goffman as impression management. To manage impression about ourselves, we use 3 -settings and these are:

- Social setting: The place or environment where our action or behavior unfolds

- Appearance: How we look when performing our roles on the social stage. e.g. How doctors, Lawyers, Lecturers, Nurses, Army etc. dresses or behave in their profession while performing their official duties.

- Manner: The attitudes we demonstrate while playing our roles. Should it involve confidence, arrogance or pride as it is expected of soldiers or care as Nurses, Intelligence as it is expected of Professors and Lecturers, expertise as expected of Doctors or Pilots.

\section{Limitations and criticisms of the symbolic interactionist school}

First, the symbolic interactionist school has been criticized for a number of reasons. First, their postulations cannot explain humans' behavior towards supernatural beings. For instance, people that worship idols, God or other supreme beings do so for a variety of reasons. The postulations of the interactionist school are not sufficient enough to explain why people bow down to idols, why people hold on to certain beliefs or make sacrifices to supreme beings.

Secondly, people can or have a calculated behavior towards others by simply interpreting his symbols or self-concept deceitfully in order to gain some sensitive information from the people he is interacting with. For instance, Secret Service Agents who wants to know how highly rated arm robbers carry out their operation may decide to join a robbery gang to gain more access into operation strategies and at this level, he will have a deceitful interpretation of himself.

Finally, Ervin Goffman's Dramaturgy came under attack for a number of reasons. First, Alvin Gouldner attacked Goffman for rationalizing society's alienation of relationships based on superficial attributes, such as appearance rather than substantial attributes such as skill.

Secondly, the dramaturgical theory cannot explain how during periods of crisis such as war or the emergence of natural disasters; why people don't manage their appearances or play out their assigned role but show their natural behavior since they are in between life and death and they don't care who is watching them or what their social assigned role is. Also, Alvin felt that, Goffman's theory only applied to people who are afraid to be themselves and not those who are satisfied with their personality and are ready to show it anywhere [11-13]. Finally, Goffman's dramaturgy cannot explain the reason behind the behavior of insane or mentally derailed persons. The symbolic interactionist school though useful in explaining certain Behaviors, is limited by these highlighted scenarios. These limitations bring us to the Social Exchange theory of human Behavior.

\section{The Social Exchange Theory and Human Behavior}

The social exchange theory starts with the presupposition that, social behavior is based on the innate human desire to minimize cost and maximize benefits. Hence, human action or behavior is controlled by things that are beneficial to them while refraining from the ones that are not beneficial to them. A basic belief according to the social exchange theory is that, social relationships occur in a social market place in which people give in order to get back. People with greater resources in the social exchange realm have greater powers over those with limited resources and have a greater control on the behavior of those with limited resources. Those in the realm of the social exchange believe that, we do things or exhibit certain behavior because we want something in return. They believe that, as a student you put in effort and time to do assignments because you want to get a good mark from the lecturer who possesses the power (resources) to award this mark to you. The citizens of a particular state, local government or community will support the government in power because they want the government to remember them in the area of employment or project allocation. This can also be used to explain why parents care for their children when they are young; so that they can receive the same care when they are old. People don't just help beggars on the street; they do so because there is a supernatural being or force that will bless them in return for the kind they have done. The social exchange theory can also be used to explain why people contest for elections and why citizens come out to vote during elections. Though it has a few limitations, this theory explains certain human behavior with regard to inter group relations and interaction among members of a society. Students for example, give their notes, textbooks or other educational materials to their class mates because they know they will be reciprocated in return when they are also in need.

\section{Limitations and criticisms}

The Social Exchange theory forgot to explain the role that socialization play in the behavior of individuals in society. It is also criticized for failing to explain the reward that humans get for responding or adapting their behavior to cope with environmental 
factors such as cold, heat, winter or earthquake in their society. The limitations identified in the social exchange theory take us to the postulations of Erving Goffman in the dramaturgical analysis.

\section{Theories of Behaviorism and the Prediction of Certain Future Actions in Nigeria}

- Using the symbolic interactionist perspective and based on observed symbols, and reactions from the citizens of South Africa and the reoccurrence of Xenophobic attacks, we can predict that, the number of Nigerians migrating to South Africa for long-term residence will reduce, and the number of Nigerians seeing South Africa as a destination for migration will reduce based on the formed symbols Nigerians have about South Africa and her citizens.

- The socio-political and economic structure of a society (as explained by the functionalist and Marxist perspective of Behavior) to a large extent determines the way or type of behavior; people exhibit in their society. Thus, it can be predicted that the sectional movement or militancy group in the country will increase, and this would propel some session, ethnic groups or regions in the country to break away, and this may result in large scale political apathy or war in Nigeria in years to come.

- The outcome of Nigeria's 2019 election can be predicted based on the observed symbols or meaning people are attaching to this present administration. The common man (i.e. majority of the electorate) wants food on his or her table, and that is her interpretation of a good government. But activities of the current regime had affected the cost of livelihood, and this may result in re-defining the symbols attached to the present administration. The symbols or meaning the common man attached to this present administration is hardship. Hence, majority of the electorates will in the 2019 election (if elections are free and fair) cast their vote for someone who promised to reduce their cost of living and hunger.

- Based on increased urbanization and cities in Nigeria, we can use the theories of Behaviorism such as the functionalist theory to predict that, there will be less informal relationships among family members due to migration, increase in divorce rate, suicide rate or marital instability due to the change in family relationships.

- Using the feminist perspective of human Behavior, it could be predicted that, more and more women in the future will be independent and unmarried because of seeing themselves as being able to do what men could do; or as a result of their increased access to education and paid employment.

- Finally, the Marxist approach to behavior can be used to predict the future of Nigeria's education and entertainment industry. Since aspects of entertainment industry such as music or football pays more financially than education in Nigeria, more and more parents or youths will direct their attention or that of their children, to make a career in music and football.

\section{Conclusion}

From the foregoing and based on the examples of theories we have reviewed so far, it could be said that, the Behaviorist approach and its theories are useful in explaining human Behavior in our society $[14,15]$. From the functionalist perspective to the Marxist and feminists, the social action of Weber and the symbolic interactionist school, social exchange theory and dramaturgy; were all tailored to explain human Behavior from the various perspectives through which human Behavior could be understood. Though the theories of Behaviorism considered so far are efficient in explaining some aspects of human Behavior, they are limited in some ways as have been highlighted above. Thus, if some or all of the above highlighted theories are dropped, the ethnographical approach which requires participant observation will be suffice in replacing the Behavioral approach or in explaining human Behavior. This is because, the ethnographical approach requires the observer to participate in the activities or processes that those being observed are also undergoing; and this could help in getting an in-depth understanding of the person or peoples' Behavior.

\section{References}

1. Skinner BF (1938) The behavior of organisms New York: Appleton Century Crofts.

2. Gouldner AW (1980) The Coming Crisis of Western Sociology New York: Basic Books Haralamboss et al (2013), Sociological Themes and Perspectives, Harper Collins Publishers, London.

3. Nicholson J (1993) Men and Women: How Different Are They? Oxford University Press, Oxford.

4. Henslin J (1993) Sociology A Down-to-Earth-Approach, Massachusetts, Ally and Bacon, 160 Gould Street Coser L. (1971), Masters of Sociological Thought: Ideas in Historical and Social Context, New York.

5. Biglan A (2015) The need for a more effective science of cultural practices. The Behavior Analyst.

6. Einstein A, Infeld L (1938) The evolution of physics New York: Simon and Schuster.

7. Freedman D (2015) Improving public perception of behavior analysis. The Behavior Analyst.

8. Hyten C (2009) Strengthening the focus on business results: the need for systems approaches in organizational behavior management. Journal of Organizational Behavior Management 29: 87-106.

9. Krapfl JE, Kruja B (2015) Leadership and culture. Journal of Organizational Behavior Management 35: 28-43.

10. Malott $M$ (2015) What studying leadership can teach us about the science of behavior. The Behavior Analyst.

11. Mattaini M, Aspholm R (2015) Contributions of behavioral systems science to leadership for a new progressive movement. The Behavior Analyst.

12. Russel B (1927) An outline of philosophy New York: WW Norton.

13. Skinner BF (1974) About behaviorism New York: Alfred A Knopf.

14. Smith J (2015) Strategies to position behavior analysis as the contemporary science of what works. The Behavior Analyst.

15. Whitehead AN (2010) Process and reality 4 New York: Simon \& Schuster. 